\title{
Platanthera species with amphora-like spurs in NE India
}

\author{
Magnus Lidén ${ }^{2}$ and Pankaj Bharali ${ }^{1}$ \\ Uppsala university, EBC: Systematic Biology. Norbyvägen 18D, 75236 Uppsala, Sweden.. \\ ${ }^{1}$ DBT-Centre of Excellence in Bioresources and Sustainable Development, DBT-APSCS\&T, Kimin-791121, \\ Papumpare District, Arunachal Pradesh, India \\ ${ }^{2}$ Communicating author; e-mail: Magnus.Liden@ebc.uu.se
}

[Received 09.04.2017; Revised \& accepted 16.05.2019; Published 30.06.2019]

\begin{abstract}
Platanthera contigua, P. uniformis, P. roseotincta and P. urceolata are all characterised by short amphora-like spurs and were previously (with the exception of $P$. roseotincta) often separated as the genus Diphylax. P. urceolata and P. uniformis are similar, whereas $P$. contigua and $P$. roseotincta are morphologically distinct. The latter three species were not known from India until recently. We here report them from alpine meadows of Upper West Siang and Upper Dibang areas of Arunachal Pradesh, India. The four species are not each others closest relatives, according to molecular trees. Their NW Yunnan/N Myanmar/SE Tibet/E Arunachal Pradesh distribution is paralleled by several other species (see Lidén \& Adhikari, this volume).
\end{abstract}

Key words: Platanthera, Amphora-like spur, NE India

\section{INTRODUCTION}

The genus Diphylax (Orchidaceae) was established by J.D. Hooker in 1889, based on the sole species Habenaria urceolata C.B.Clarke. Soon, however, he reduced it to Habenaria (Hooker 1894) as a section, described as "flowers small, secund; lip entire; spur short, fusiform. Anther with a setiform staminode on each side as long as itself". The genus was resurrected by Kräntzlin (1899), and expanded to include $H$. griffithii Hook.f. This is a remotely related species, now in a monotypic genus Nujiangia (Jin \& al. 2012). In 1940, Tang \& Wang described two new species of Platanthera, $P$. uniformis and P. contigua, which were transferred to Diphylax in 1989 and 1994, respectively.

A DNA sequence analysis by Jin $\&$ al. (2014) shows that it makes little sense keeping Diphylax as a genus separate from Platanthera, as the Diphylax species do not group together in phylogenetic trees. P. urceolata forms a clade with $P$. [Smithorchis] calceoliformis and $P$. [Herminium] carnosilabris, wheras $P$. uniformis surprisingly does not group with the closely similar $P$. urceolata, but instead with $P$. contigua with high support. Finally, $P$. roseotincta come together with several Himalayan species in a poorly resolved clade.

\section{Recent observations}

During two expeditions to alpine areas of Arunachal Pradesh - Mechuka, Upper West Siang (Bharali and Lidén in 2014) and Anini, Upper Dibang (Adhikari and Lidén in 2017) - three orchids of the Platanthera alliance with short urceolate spurs were recorded. They did not match any species hitherto known from India (Lang 1994; Rao 2010; Kush 2015; e-resources). Consulting Flora of China and comparing with herbarium specimens at PE (Beijing) revealed that we had found P. contigua, hitherto known from NW Yunnan, P. roseotincta, from NW 


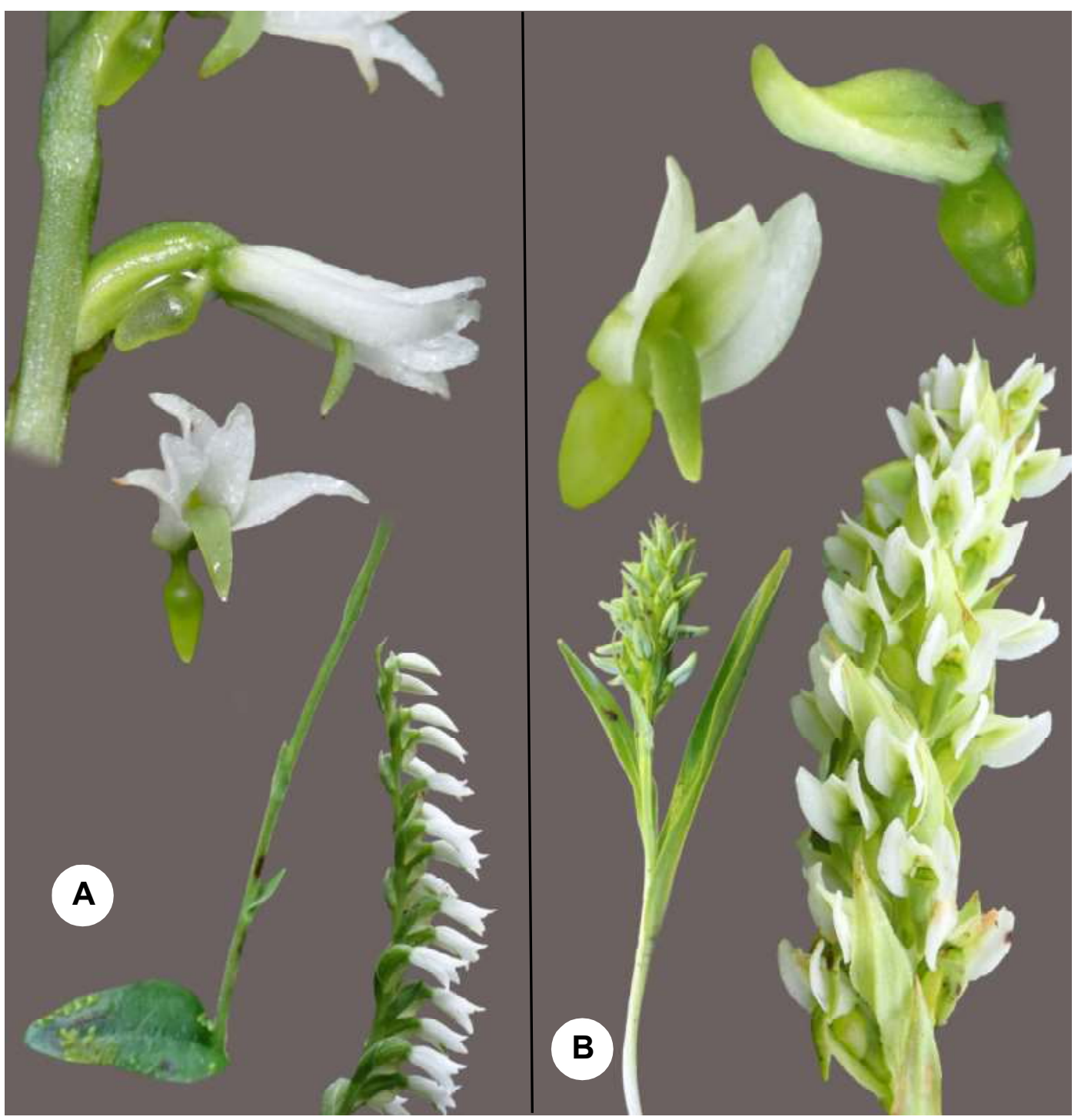

PLATE-I. Platanthera uniformis (left): Adhikari \& Lidén 137; P. contigua (right); inflorescence and open flower Adhikari \& Lidén 136, whole plant and flower bud Bharali \& Lidén 2014-4.

Yunnan, N Myanmar and SE Tibet (Medog, Zayü) and P. uniformis from SW China and SE Tibet.

In no case did we observe pollination, partly due to heavy rain, but it would be interesting to know if there is a correlation between urceolate spur and pollinator.

\section{The species}

Platanthera roseotincta (W.W.Smith) Tang \& F.T.Wang, Bull. Fan Mem. Inst. Biol. Bot. 10: 30. 1940.

Distributed in SE Tibet, NW Yunnan, N Myanmar and Arunachal Pradesh (Upper West Siang). For specimen records and photos, see Bharali \& al. (2018). 
Platanthera contigua Tang \& F.T.Wang. Bull. Fan Mem. Inst. Biol. Bot. 10: 28. 1940. Diphylax contigua (Tang \& F.T.Wang) Tang, F.T.Wang \& K.Y.Lang, Vasc. Pl. Hengduan Mount. 2: 2526. 1994. Type: Salween/ Kiukiang divide, Lunguailaka, $3200 \mathrm{~m}$, under bamboo thickets, flowers greenish white. 16 September 1938. T.T. Yü 20328 (PE).

With its dense non-secund inflorescence it cannot be confused with any other "Diphylax" orchid. It was first found in bamboo thickets at $3200 \mathrm{~m}$, but was later collected in the Gaoligongshan up to $4200 \mathrm{~m}$. It has recently been found in two localities in Arunachal Pradesh: Domjeela N of Mechuka (Upper W Siang), where it is quite common in alpine meadows at $3800-4000 \mathrm{~m}$, often in company with the likewise fairly common $P$. roseotincta. It was later recorded also from Anini (Upper Dibang), but here we saw only two small patches with about 10 flowering stems each, growing close to the forest line on the margin of a gravelly slope at $3650 \mathrm{~m}$ and in a wet meadow at $3800 \mathrm{~m}$.

Arunachal Pradesh: West Siang, 13 km N Mechuka, Domjee La, $28^{\circ} 42^{\prime} \mathrm{N}$; $94^{\circ} 05^{\prime} \mathrm{E}, 3800$ - 3900 m, alpine meadow. 24 August 2014. Bharali \& Lidén 2014-4 (CAL); Upper Dibang, NE Anini, $28^{\circ} 49^{\prime} \mathrm{N} ; 96^{\circ} 2^{\prime} \mathrm{E}, 3650 \mathrm{~m}, 8$ September 2017. Adhikari \& Lidén 136 (CAL); Yunnan: Gongshan: Dulong Jiang, Yakou, 4200 m. 24 August 2006. Jin XH 8398 (PE); Danzhu path, alpine meadow. 30 July 2013. Jin XH, Wang LS, Wang $Q$, Wei R, Fu ZX \& Feng YL ST1522 (PE); Gawagapu peak, Bingzhongluo, $2700-3700 \mathrm{~m}$, conifer forest to alpine meadow. 3 August 2013. Jin XH \& al. ST1717 (PE); id, 3700 - $4231 \mathrm{~m}$, alpine meadow. 3 August 2013. Jin XH \& al. ST1762 (PE); Jin XH 8398 (PE, not seen, fide Jin \& al. 2014).

Platanthera uniformis Tang \& F.T.Wang, Bull. Fan Mem. Inst. Biol. Bot. 10: 31. 1940. Type: NW Yunnan, Salween/Kiukiang divide, E of Wangtzang, 2900 m. 13 November 1938. T.T. Yü 20233, 20244 (PE).

Similar to $P$. urceolata, but leaves comparatively much broader (2 - 4 vs $1-1.5 \mathrm{~cm})$, and possibly more soft and fleshy; bract-like leaves below the raceme 3 to 4 (vs 1 to 2); raceme with 9 to 23 (vs 6 to 12) flowers; bracts shorter than ovaries (vs at least as long); flowers 7 $-8 \mathrm{~mm}$ long (vs $5 \mathrm{~mm}$ ); lateral sepals parallel (vs diverging); petals equalling (vs shorter than) sepals; staminodes elliptic-obtuse, shorter than anther (vs linear, equalling anther).

This we found near the Mayodia pass (Lower Dibang), and later NE of Anini (Upper Dibang), in both places growing scattered in mature forest.

Arunachal Pradeshah: Upper Dibang, NE Anini, 28 49' N; 96 02' E, 3200 m, 8 September 2017. Adhikari \& Lidén 137 (CAL); Lower Dibang, Mayudia pass, $28^{\circ} 14.2^{\prime} \mathrm{N}$; $95^{\circ} 56^{\prime} \mathrm{E}$ 2700 m. 17 September 2017. Lidén (photo); SE Tibet: Zayu, Zhuwagen, Sangjiu, forest, 3800 m. SE Tibet expedition team (SET-ET) 867 (PE); Also NW Yunnan, Sichuan and Guizhou (PE).

Platanthera urceolata (C.B.Clarke) R.M.Bateman, Ann. Bot. (Oxford) 104(3): 439. 2009 - Habenaria urseolata C.B.Clarke, J. Linn. Soc., Bot. 25: 73 t. 30. 1889. Diphylax urceolata (C.B.Clarke) Hook.f., Hooker's Icon. P1. 19: ad t. 1865. 1889. - Type: Naga Hills, Jakpho, 9000 ft. [2743 m], 15 October 1869. C. B. Clarke 41272 (K-holo, lower specimen; only pencil drawings available on $\mathrm{K}$ web-site, but original specimen photographed in the thesis of Law Kush 2015).

A cautious disclaimer: Clarke's original description and illustration is based on a specimen from Nagaland with anecdotical reference to an earlier Clarke specimen: "Sir J. D. Hooker has pointed out to me that I formerly collected this plant in Eastern Sikhim (Takha Valley), and that I then noted two linear processes pointing obliquely forward in the mouth of the corolla". Clarke's Naga specimen is vegetatively intermediate between P. urceolata (basal leaf 
lanceolate; bracts longer than ovaries) and P. uniformis (3 to 4 bractlike leaves; raceme ca 15-flowered), and it is not certain that the added floral details in Hooker's plate (1889) come from the type specimen. However, the rather distinctive leaf lead us to believe that the current application of the name is correct.

\section{LITERATURE CITED}

Bahrali, P., Das, A. K. \& Lidén, M. 2018. Notes on the alpine flora of Arunachal Pradesh, including several species new to India. In: A. P. Das \& Subir Bera (eds), Plant diversity in the Himalaya hotspot region. Vol. 1: 163 - 194. Bishen Singh Mahendra Pal Singh, Dehradun.

Hooker, J.D. 1894. The Flora of British India, vol. 6. L. Reeve \& Co, London.

Jin Xiao-Hua, Li De-Zhu., Xiang Xiao-Guo, Lai Y-J \& Shi X-C, 2012. Nujiangia (Orchidaceae: Orchideae): a new genus from the Himalayas. J. Syst. Evol. 50: 64-71.

Jin Wei-Tao, Jin Xiao-Hua, Schuiteman, A., Li De-Zhu, Xiang Xiao-Guo, Huang Wei-Chang, Li Jian-Wu \& Huang Lu-Qi. 2014. Molecular systematics of subtribe Orchidinae and Asian taxa of Habenariinae (Orchideae, Orchidaceae) based on plastid matK, rbcL and nuclear ITS. Molecular Phylogenetics and Evolution 77: 41-53.

Kränzlin, F. 1899. Orchidacearum genera et species, vol. 1. Mayer and Müller, Berlin.

Kush, L. 2015. Taxonomic revision of subtribe Habenariinae Bernh. (Orchidaceae) in India. $\mathrm{PhD}$ Thesis, Kumaon university, Nainital. https://shodhganga.inflibnet.ac.in/ bitstream/10603/160227/12/lawkush\%20thesis.pdf

Lang Kai-Yong. 1994. Studies on the distribution patterns of some significant genera in orchid flora. Acta Phytotaxonomica Sinica 32 (4): 328 - 339.

Rao, A.N. 2010. Orchid flora of Arunachal Pradesh. Bull. Arunachal For. Res. 26(1\&2): $82-110$.

e-resources

e-Flora of India: http://efloraindia.nic.in. Accessed December 2017.

Flora of China on the web: http://flora.huh.harvard.edu/china. Accessed December 2017.

Flora of Pan-Himalaya: http://www.flph.org. Accessed December 2017.

IBIS-Flora: Deomurari, A., Minal Jani, M., Komal Matieda, J. Patel and A. Parmar.: http:// flora.indianbiodiversity.org. Accessed December 2018. 